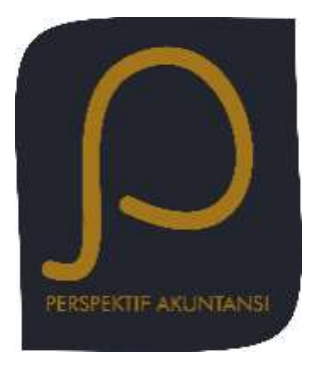

Perspektif Akuntansi

Volume 2 Nomor 1 (Februari 2019), hal.71-88

ISSN: 2623-0194(Print), 2623-0186(Online)

Copyright(C) The Authors(s). All Rights Reserved

Fakultas Ekonomika dan Bisnis,

Universitas Kristen Satya Wacana

DOI: https://doi.org/10.24246/persi.v2i1.p71-88

http://ejournal.uksw.edu/persi

\title{
Mengapa Perusahaan Terlambat Menerbitkan Laporan Keuangan?
}

Winda Felicia

Fakultas Ekonomika dan Bisnis, Universitas Kristen Satya Wacana

David Adechandra Ashedica Pesudo ${ }^{1}$

Fakultas Ekonomika dan Bisnis, Universitas Kristen Satya Wacana

Received Abstract. Purpose of this research is to assess whether there is a 06/01/2019 difference between financial statements audit with on time and late publication date. it can be seen through the size pf the company,

Accepted

$10 / 01 / 2019$ profit/loss operation, KAP reputation, solvability and profitability of mining public company which are recorded from 2014 until 2016 in Indonesia Stock Exchange. Total sample of this study is 102 using purposive sampling.The data is analyzed by non-parametic test. Results showed that there is a difference on the company's size, profit/loss operation and KAP reputation, but there is no difference on the solvability and profitability between company that published their financial statements on time and late.

Keywords: financial statement, audit, timeliness, company size, solvability, profitability

Abstrak. Penelitian ini bertujuan untuk mengetahui ada tidaknya
perbedaan laporan keuangan auditan yang disampaikan tepat waktu
dan laporan keuangan auditan yang disampaikan tidak tepat waktu
dilihat dari sisi ukuran perusahaan, laba/rugi operasi, reputasi KAP,
solvabilitas dan profitabilitas pada perusahaan publik pertambangan
yang tercatat di Bursa Efek Indonesia pada tahun 2014 sampai 2016 .
Total sampel perusahaan dalam penelitian ini adalah 102 sampel yang
diperoleh dengan metode purposive sampling. Data dalam penelitian
ini dianalisis menggunakan pengujian statistik non parametrik yakni
Uji Mann-Whitney. Hasil penelitian ini menunjukkan bahwa terdapat

1 david.pesudo@staff.uksw.edu 
perbedaan ukuran perusahaan, laba rugi operasi, dan reputasi KAP pada laporan keuangan yang disampaikan tepat waktu dan laporan keuangan yang di penyampaian terlambat. Namun tidak ada perbedaan profitabilitas dan solvabilitas perusahaan pada laporan keuangan yang disampaikan tepat waktu dan laporan keuangan yang di penyampaian terlambat.

Kata kunci: laporan keuangan, audit, ketepatan waktu, ukuran perusahaan, solvabilitas, profitabilitas

\section{Pendahuluan}

Pengambilan keputusan bagi pihak berkepentingan dalam suatu perusahaan didasari oleh informasi yang jelas mengenai laporan keuangan. Pihak-pihak berkepentingan tersebut yakni manajemen, investor, karyawan, kreditor, pemerintah, pelanggan, dan masyarakat berdasarkan dengan tujuan dan motivasi yang dimiliki. Laporan keuangan menjadi sumber informasi sangat berguna karena laporan keuangan menggambarkan kinerja keuangan, perubahan ekuitas, arus kas, dan aktiva yang ada dalam perusahaan. Laporan keuangan dikatakan bermanfaat ketika informasi keuangan yang disajikan relevan, andal, dapat dibandingkan, dan dapat dipahami (Ikatan Akuntansi Indonesia, 2018).

Sumber dan referensi informasi akuntansi yang paling relevan dan andal yaitu laporan keuangan yang telah diaudit bagi pengguna eksternal (Alkhatib \& Marji, 2012). Audit merupakan pemeriksaan mengenai laporan keuangan yang diberikan oleh manajemen dengan bukti-bukti pendukung yang ada dan dilakukan secara sistematis dan kritis oleh auditor yang bertujuan untuk memberikan opini tentang wajarnya sebuah laporan keuangan (Arens, Elder, Beasley, \& Hogan, 2017). Berdasarkan definisi di atas maka laporan keuangan semestinya dan sebaiknya diaudit agar dapat memahami apakah laporan keuangan terdapat salah saji atau tidak, apakah ada kesalahan disengaja atau tidak. Jika laporan keuangan tidak diaudit maka laporan keuangan kurang dapat diandalkan kewajarannya oleh pihak eksternal yang memiliki kepentingan terhadap laporan keuangan tersebut. Auditor eksternal yang bekerja di luar dari perusahaan yang melakukan audit atas laporan keuangan. Auditor eksternal tersebut bekerja di Kantor Akuntan Publik (KAP) dan merupakan pihak ketiga independen. Laporan auditor yaitu hasil pemeriksaan independen dan pendapat/opini atas laporan keuangan perusahaan. Auditor eksternal mewajibkan suatu laporan keuangan agar diaudit untuk memberikan opini tentang kewajaran laporan keuangan yang artinya bahwa laporan keuangan yang diberikan manajemen perlu verifikasi apakah sudah sesuai dengan standar pelaporan yang ada (Arens, Elder, Beasley, \& Hogan, 2017). 
Syarat yang harus dimiliki dalam laporan keuangan yang baik yaitu relevan, andal, dapat dipahami dan tepat waktu. Ketepatan waktu menyusun laporan keuangan akan berdampak pada nilai laporan keuangan tersebut, laporan keuangan merupakan alat komunikasi dalam kegiatan operasional dan keuangan perusahaan dalam satu periode tertentu yang berguna untuk mendeskripsikan kinerja suatu perusahaan. Ketepatan waktu meningkatkan antara relevansi dan informasi pengungkapan penuh yang menambah kualitas karakteristik laporan keuangan. Ketepatan waktu dalam menyampaikan laporan keuangan dan lamanya waktu menyelesaian audit (audit delay) sebagai tolak ukur keberhasilan sebuah perusahaan merupakan prasyarat utama agar dapat meningkatkan kualitas perusahaan (Wariyanti \& Suryono, 2017)

Fenomena yang terjadi yaitu Bursa Efek Indonesia (BEI) masih saja menemukan terlambatnya pelaporan keuangan oleh perusahaan-perusahaan publik. Pada 9 April 2015 BEI melaporkan total 52 perusahaan emiten yang belum menyampaikan laporan keuangan audit per Desember 2014 (Nabhani, 2015). Sampai tanggal 29 Juni 2015 ada enam perusahaan emiten per 31 Desember 2014 belum menyampaikan laporan keuangannya, sehingga BEI mensuspensi enam perusahaan tersebut (Sukirno, 2015). BEI juga mensuspensi perdagangan saham 18 perusahaan tercatatat karena belum memberikan laporan keuangan audit periode 31 Desember 2015 (Pasopati, 2016). Terdapat 17 perusahaan emiten yang disuspensi karena belum memberikan laporan keuangan auditan per 31 Desember 2016 serta belum membayar denda terlambat dalam menyampaikan laporan keuangan (Melani, 2017). Meskipun BEI telah memberikan sanksi kepada perusahaan emiten yang terlambat melaporkan laporan keuangan auditan, akan tetapi penyampaian laporan keuangan auditan yang terlambat terus terjadi setiap tahun. Dengan demikian, hal ini menjadi krusial dan menjadi perhatian perusahaan dalam hal menangani keterlambatan pelaporan keuangan. Masalah mengenai tingkat kedisiplinan emiten berkaitan dengan laporan keuangan yang terlambat disampaikan berhubungan dengan rentang waktu auditor dalam mengaudit laporan keuangan.

Pentingnya pengaruh ketepatan waktu penyampaian dengan laporan keuangan yang relevan sebagai dasar utama pengambilan keputusan penggunanya menjadi alasan untuk melakukan penelitian mengenai hal apa saja yang menjadi penyebab keterlambatan penyampaian laporan keuangan auditan. Rumusan masalah pada penelitian ini adalah apakah ada perbedaan pada ukuran perusahaan, laba/rugi operasi, reputasi KAP, solvabilitas dan profitabilitas di dalam laporan keuangan auditan yang disampaikan tepat waktu dan laporan keuangan auditan yang di penyampaian terlambat? Selanjutnya penelitian ini bertujuan untuk menguji ada tidaknya perbedaan 
laporan keuangan auditan yang disampaikan tepat waktu dan laporan keuangan auditan yang disampaikan tidak tepat waktu dilihat dari sisi ukuran perusahaan, laba/rugi operasi, reputasi KAP, solvabilitas dan profitabilitas pada perusahaan publik pertambangan yang tercatat di BEI. Manfaat dari penelitian ini yaitu membantu perusahaan emiten dalam hal ketepatan waktu menyampaikan laporan keuangan yang telah diaudit.

\section{Telaah Pustaka}

\section{Laporan Keuangan}

PSAK No. 1 tentang Penyajian Laporan Keuangan menyatakan laporan keuangan berisikan posisi keuangan dan kinerja keuangan yang disajikan secara terstruktur. Laporan keuangan merupakan informasi tertulis mengenai keuangan suatu perusahaan dalam satu periode tertentu (misal laporan keuangan bulanan, laporan keuangan tiga bulanan, laporan keuangan semesteran dan laporan keuangan tahunan) yang menggambarkan kinerja suatu perusahaan. Laporan keuangan mencerminkan seluruh transaksi akuntansi selama periode tertentu yang memberikan informasi mengenai kondisi perusahaan mengenai peningkatan dan penurunan nilai bersih ekonomi untuk pemilik dan pemegang saham perusahaan (Rachman, 2016).

Tujuan dari laporan keuangan yaitu untuk menyajikan informasi tentang posisi keuangan, arus kas perusahaan, dan kinerja yang memiliki manfaat bagi pengguna laporan keuangan dalam membuat keputusan ekonomi serta memberikan pertanggungjawaban pengelola perusahaan atas sumber-sumber daya yang diserahkan kepada manajemen (Mubarok, 2016). Pengguna informasi tersebut digunakan dua pihak pengguna yakni pengguna internal dan eksternal. Pengguna eksternal yaitu kreditor, investor, pemberi pinjaman, pemasok, pelanggan, pemerintah dan masyarakat. Sementara pengguna internal yaitu pemilik perusahaan dan manajer.

\section{Ketepatan Waktu Publikasi Laporan Keuangan}

Suatu informasi dapat dikatakan tepat waktu yakni ketika informasi harus disampaikan sedini mungkin agar dapat berguna sebagai dasar dalam pengambilan keputusan ekonomi dan supaya dapat menghindari tertundanya pengambilan keputusan tersebut (Panjaitan, Wahidahwati, \& Amanah, 2013). Informasi dapat bermanfaat bagi penggunanya jika informasi tersebut diungkapkan tepat waktu (Rachmawati, 2008). Oleh sebab itu, ketepatan waktu merupakan hal yang penting karena tepat atau tidaknya waktu penyampaian laporan keuangan berpengaruh besar pada keputusan yang diambil oleh manajemen nantinya. 
Keputusan Nomor 307 mengacu pada ketentuan II.6.4 Peraturan Nomor I-H tentang sanksi, Bursa mensuspensi apabila mulai hari kalender ke-91 sejak lampaunya batas waktu penyampaian laporan keuangan, perusahaan tercatat tidak memenuhi kewajiban penyampaian laporan keuangannya (Melani, 2017). Oleh karena itu, keterlambatan penyampaian laporan keuangan auditan yakni ketika setelah 90 hari atau 31 Maret setelah tanggal berakhirnya tahun buku perusahaan.

\section{Audit Laporan Keuangan}

Tujuan audit yaitu untuk menyatakan pendapat atas wajarnya semua hal yang material, posisi keuangan hasil usaha dan arus kas yang sesuai dengan prinsip akuntansi yang berlaku (Arens, Elder, Beasley, \& Hogan, 2017). Laporan keuangan yang wajar dinilai dari asersi yang terdapat pada unsur yang ada dalam laporan keuangan. Asersi yang dimaksud yaitu pernyataan manajemen secara tersirat di dalam komponen laporan keuangan.

Lamanya waktu penyelesaian laporan keuangan yang diaudit oleh auditor eksternal tidak dapat diprediksi sehingga ada kemungkinan terlambat. Hal ini juga dikarenakan dalam Standar Pemeriksaan Akuntan Publik pada standar ketiga yang menyatakan bahwa audit harus dilaksanakan dengan penuh kecermatan dan ketelitian serta pengumpulan alat-alat pembuktian yang cukup memadai (Arens, Elder, Beasley, \& Hogan, 2017). Semakin lama penyelesaian audit laporan keuangan dapat memicu efek negatif terhadap perusahaan karena lambatnya laporan audit, menyebabkan informasi akuntansi menjadi tidak andal dan tidak relevan serta dapat menciptakan kurangnya kepercayaan investor.

\section{Pengembangan Hipotesis}

\section{Perbedaan Ukuran Perusahaan}

Besar kecilnya ukuran perusahaan ditunjukkan oleh total asset suatu perusahaan pada akhir periode. Total penjualan juga dapat digunakan dalam mengukur besar kecilnya perusahaan. Ukuran suatu perusahaan dapat diketahui berdasarkan lapangan usaha yang dijalankan. Kategori perusahaan yang besar biasanya melaporkan laporan keuangan lebih cepat dibandingkan perusahaan yang lebih kecil. Perusahaan besar cenderung memiliki pengendalian internal yang baik dan manajemen perusahaan yang berskala besar cenderung menerima insetif untuk mempersingkat lamanya waktu audit karena dipantau secara ketat oleh pengawas permodalan dari pemerintah (Panjaitan, Wahidahwati, \& Amanah, 2013). Ukuran perusahaan yang besar cenderung mempunyai staf akuntansi yang lebih banyak sehingga lebih cepat dalam menyelesaikan laporan keuangannya. 
Pada penelitian Susilo \& Fatmayeti (2015) membuktikan bahwa ukuran perusahaan berpengaruh positif pada ketepatan waktu penyampaian laporan keuangan. Penelitian ini menduga bahwa perusahaan besar mendapat tekanan dalam membuat laporan keuangan agar tepat waktu dalam penyampaiannya. Oleh karena itu, manajemen perusahaan akan bekerja semaksimal mungkin sehingga proses penyusunan laporan keuangan dapat diselesaikan tepat waktu. Dengan demikian, ketepatan waktu laporan keuangan yang di penyampaian bergantung pada kecil besarnya ukuran perusahaan. Berdasarkan penjelasan di atas, maka dapat dirumuskan hipotesis berikut:

$\mathbf{H}_{1}$ : Terdapat perbedaan ukuran perusahaan pada laporan keuangan auditan yang tepat waktu dengan laporan keuangan auditan yang terlambat.

\section{Perbedaan Laba/Rugi Operasi}

Laporan laba/rugi suatu perusahaan biasanya yaitu laporan keuangan yang pertama kali dibaca karena pada kenyataannya tujuan perusahaan yaitu untuk menghasilkan keuntungan. Laba yang diraih perusahaan mengartikan majunya keuangan perusahaan, sedangkan rugi yang didapatkan perusahaan berarti mundurnya keuangan perusahaan. Ada dua alasan perusahaan yang rugi dapat mengalami keterlambatan penyampaian laporan keuangan. Pertama, ketika terjadi kerugian maka perusahaan akan menunda berita buruk tersebut sehingga perusahaan akan meminta auditor untuk menjadwal ulang penugasan audit. Kedua, auditor akan lebih berhati-hati dalam melakukan proses audit ketika yakin bahwa kerugian ini disebabkan karena gagalnya keuangan perusahaan ataupun kecurangan manajemen mengenai laba perusahaan (Kartika, 2011).

Pada penelitian Tamba (2010) menunjukkan bahwa laba rugi perusahaan memiliki pengaruh pada lamanya audit laporan keuangan. Penelitian Kartika (2011) serta Puspitasari \& Sari (2012) menunjukkan bahwa laba rugi operasi memiliki pengaruh negatif dan signifikan terhadap keterlambatan penyampaian laporan keuangan perusahaan. Hal itu disebabkan karena perusahaan yang memiliki laba akan melakukan proses audit lebih cepat dibandingkan perusahaan yang mengalami rugi. Ketika laporan keuangan perusahaan mengalami rugi, hal tersebut membuat pihak manajemen mencari alasan penyebab kerugian tersebut, yang mengakibatkan pihak manajemen cenderung terlambat dalam melaporkan laporan keuangan. Perusahaan yang mengalami rugi diduga akan terlambat melaporkan keuangan auditan dibandingkan ketika perusahaan mengalami laba akan melaporkan keuangan yang tepat waktu. Berdasarkan penjelasan di atas, maka dapat dirumuskan hipotesis berikut: 
$\mathbf{H}_{2}$ : Terdapat perbedaan laba/rugi operasi pada laporan keuangan yang tepat waktu dengan laporan keuangan yang terlambat pada perusahaan pertambangan di BEI.

\section{Perbedaan Reputasi KAP}

Kualitas auditor merupakan gabungan kemungkinan pendeteksian dan pelaporan kesalahan yang material (Sari, Setiawan, \& Ilham, 2014). KAP yang lebih besar (The Big Four) memiliki kualitas audit yang lebih baik. Kualitas audit yang baik akan menghasilkan reputasi KAP yang baik juga. KAP The Big Four di Indonesia yakni KAP Tanudiredja, Wibisana \& Rekan (PwC), KAP Osman Bing Satrio (Deloitte), KAP Purwantono, Suherman \& Surja (EY), serta KAP Sidharta dan Widjaja (KPMG). KAP The Big Four dianggap mampu melaksanakan pemeriksaan audit secara lebih efisien dan memiliki jadwal waktu audit yang tinggi dalam menyelesaikan audit tepat pada waktunya karena memiliki sumber daya manusia yang kompeten.

Segi kelayakan suatu laporan keuangan dan hasil audit lainnya secara prosedur dan aturan dapat dinyatakan telah memenuhi syarat go public sangat mempengaruhi pernyataan KAP tersebut, sehingga reputasi seorang auditor akan dipertaruhkan ketika perusahaan bermasalah terhadap laporan keuangannya maka auditor serta KAP-nya akan mendapat dampak negatif seperti reputasi KAP yang dimiliki menurun (Mareta, 2015). Oleh sebab itu semakin besar suau KAP maka mendapat reputasi yang baik dipandang oleh masyarakat.

Auditor yang memiliki reputasi yang baik (KAP The Big Four) akan memberikan kualitas pekerjaan audit secara efektif dan efisien, sehingga audit mampu diselesaikan tepat waktu. Rentang waktu audit yang lebih cepat merupakan cara KAP The Big Four dalam mempertahankan dan meningkatkan reputasinya (Puspitasari \& Sari, 2012). Penelitian ini menggunakan reputasi KAP sebagai variabel independen karena dianggap mampu mempengaruhi cepat atau lambatnya proses dalam pengauditan itu sendiri yang menyebabkan laporan keuangan auditan terlambat di penyampaian. Reputasi KAP yang berafiliasi dengan The Big Four kemungkinan memiliki laporan keuangan auditan yang disampaikan tepat waktu dibandingkan dengan KAP Non Big Four memiliki laporan keuangan auditan yang di penyampaian terlambat. Berdasarkan penjelasan di atas, maka dapat dirumuskan hipotesis berikut:

$\mathbf{H}_{3}$ : Terdapat perbedaan reputasi KAP pada laporan keuangan tepat waktu dengan laporan keuangan terlambat pada perusahaan pertambangan di BEI. 


\section{Perbedaan Solvabilitas}

Solvabilitas merupakan kemampuan perusahaan dalam melunasi hutanghutangnya, baik hutang jangka pendek dan hutang jangka panjang. Perusahaan yang jumlah hutangnya lebih besar daripada total modalnya merupakan perusahaan yang tidak solvable. Semakin banyak perusahaan melakukan pembayaran melalui hutang dapat menambah risiko pada saham biasanya. Tolak ukur solvabilitas dalam penelitian ini yaitu Debt Equity Ratio (DER) yang menggambarkan perbandingan antara total hutang dengan total ekuitas/modal.

Penelitian Apriyana \& Rahmawati (2017) menjelaskan bahwa dalam memeriksa akun hutang membutuhkan waktu yang lama karena harus mencari sumber penyebab dari tingginya proporsi hutang yang dimiliki perusahaan dan membutuhkan waktu yang lama dalam mengkonfirmasi pihak-pihak (debtholder) yang berhubungan dengan perusahaan. Jumlah hutang terhadap aktiva yang tinggi mungkin membuat auditor harus mendapatkan alat bukti yang lebih banyak dan kompeten untuk meyakinkan kewajaran laporan keuangan, dan meningkatkan ketelitian dan kehati-hatian yang lebih dalam pemeriksaan karena berkaitan dengan kelangsungan hidup perusahaan (going concern) yang membuat lamanya penyelesaian audit sehingga menyebabkan laporan keuangan auditan terlambat di penyampaian. Berdasarkan penjelasan di atas, maka dapat dirumuskan hipotesis berikut:

$\mathbf{H}_{4}$ : Terdapat perbedaan solvabilitas pada laporan keuangan yang tepat waktu dengan laporan keuangan yang terlambat pada perusahaan pertambangan di BEI.

\section{Perbedaan Profitabilitas}

Profitabilitas mengukur seberapa besar kemampuan perusahaan dalam menggunakan aset untuk menghasilkan laba bagi perusahaan tersebut. Profitabilitas menunjukkan sejauh mana keuntungan perusahaan atau seberapa besar tingkat kesuksesan perusahaan. Tingkat profitabilitas setiap perusahaan berbeda-beda. Hal tersebut mempengaruhi tepat waktu atau tidaknya suatu perusahaan mempenyampaiankan laporan keuangan auditannya. Dengan demikian, semakin tinggi profit yang didapatkan maka mempenyampaian laporan keuangan perusahaan lebih cepat.

Pada penelitian Astuti \& Erawati (2018) membuktikan bahwa profitabilitas berpengaruh ketepatan waktu penyampaian laporan keuangan, sehingga diasumsikan bahwa ada perbedaan pada total nilai profitabilitas pada laporan keuangan yang tepat waktu dan laporan keuangan yang terlambat disampaikan. Berdasarkan penjelasan di atas, maka dapat dirumuskan hipotesis berikut: 
$\mathbf{H}_{5}$ : Terdapat perbedaan solvabilitas pada laporan keuangan yang tepat waktu dengan laporan keuangan yang terlambat pada perusahaan pertambangan di BEI.

\section{Metoda}

\section{Jenis Penelitian}

Jenis data penelitian ini yaitu data kuantitatif. Penelitian ini menggunakan data sekunder yang didapatkan dari sumber data yakni laporan keuangan tahunan perusahaan pertambangan yang tercatat dan disampaikan di BEI. Perusahaan pertambangan menjadi objek pada penelitian ini dikarenakan pada tahun 2014-2016 sebagian besar perusahaan yang di suspensi oleh BEI merupakan perusahaan pertambangan. Jangka waktu penelitian dipilih dari tahun 20142016 dikarenakan pada periode tersebut merupakan data terbaru dan belum diteliti oleh peneliti sebelumnya.

\section{Populasi dan Sampel}

Populasi dalam penelitian ini adalah seluruh perusahaan pertambangan yang terdaftar dalam BEI pada tahun 2014 sampai pada tahun 2016. Penelitian ini menggunakan purposive sampling sebagai pedoman dalam menentukan sampel penelitian. Kriteria pemilihan sampel pada penelitian ini yaitu: 1) Perusahaan pertambangan yang tercatat di BEI dan menyampaikan laporan keuangan secara konsisten dan lengkap dalam periode tahun 2014 sampai tahun 2016,2) Saham-saham yang secara konsisten dan tetap berada pada perusahaan pertambangan dalam periode tahun 2014 sampai tahun 2016 yang telah diaudit oleh auditor independen.

\section{Tabel 1. Teknik Pengambilan Sampel}

\begin{tabular}{lc}
\hline Keterangan & Jumlah \\
\hline Perusahaan pertambangan yang terdaftar tahun 2014-2016 & 47 \\
Perusahaan pertambangan yang delisting tahun 2014-2016 & $(9)$ \\
Perusahaan yang tidak memiliki laporan keuangan auditan tahun 2014- & $(4)$ \\
2016 & \\
Jumlah Perusahaan & 34 \\
Total Sampel yang Diuji (34 x 3 tahun) & 102 \\
\hline
\end{tabular}

Sumber: www.idx.co.id

\section{Analisis Data}

Penelitian ini membandingkan ukuran perusahaan, reputasi KAP, laba/rugi operasi solvabilitas dan profitabilitas dilihat dari dua sisi yaitu laporan keuangan yang tepat waktu dan laporan keuangan yang terlambat disampaikan. Penelitian ini menggunakan SPSS 22 dalam pengolahan data. 
Langkah analisis data dimulai dengan membuat Statistik Deskriptif. Teknik yang dilakukan pertama yaitu dengan menghitung nilai rata-rata (mean) pada seluruh variabel dependen. Setelah itu melakukan uji normalitas data. Pengujian normalitas dalam penelitian ini dilakukan dengan menggunakan uji statistik Kolmogorov-Smirnov. Level of Significant yang digunakan adalah 0,05. Data berdistribusi normal ketika nilai Asymp. Sig (2-tailed) hasil perhitungan dalam SPSS lebih dari 0,005. Setelah mengetahui data terdistribusi normal atau tidak, maka dilakukanlah uji beda.

Uji beda dalam penelitian ini menggunakan uji statistik non parametik (MannWhitney) yang bertujuan untuk menguji perbedaan rata-rata dua kelompok yang Independent ketika data tidak terdistribusi normal. Uji beda menggunakan uji statistik parametrik yakni uji beda rata-rata atau t-hitung (independent sample t-test) dengan uji satu arah yang digunakan untuk penelitian yang membandingkan dua variabel ketika data berdistribusi normal.

\section{Hasil dan Pembahasan}

\section{Hasil}

\section{Statistik Deskriptif}

Penelitian ini menggunakan lima (5) variabel independen yaitu ukuran perusahaan (X1) laba/rugi operasi (X2) reputasi KAP (X3) solvabilitas (X4) dan profitabilitas (X5) sedangkan variabel dependennya Keterlambatan Laporan Keuangan Auditan (Y).

Tabel 2. Deskripsi Data Penelitian

\begin{tabular}{|c|c|c|c|c|c|}
\hline \multirow{2}{*}{\multicolumn{2}{|c|}{ Variabel }} & Minimum & Maximum & Mean & Std. Deviation \\
\hline & & \multicolumn{4}{|c|}{ (dalam jutaan rupiah) } \\
\hline \multicolumn{6}{|c|}{ Ukuran } \\
\hline & $\begin{array}{l}\text { Peru } \\
\text { saha } \\
\text { an }\end{array}$ & 157.702 & 87.196 .053 & 11.668 .729 & 17.211.177 \\
\hline \multirow[t]{2}{*}{ Laba } & Rugi & & & & \\
\hline & $\begin{array}{l}\text { Ope } \\
\text { rasi }\end{array}$ & 30.010 & 4.554 .631 & 71.809 & 3.180 .733 \\
\hline \multicolumn{6}{|c|}{ Reputasi } \\
\hline & $\begin{array}{l}\text { Audi } \\
\text { tor }\end{array}$ & 1 & 2 & 1.47 & 0.502 \\
\hline \multicolumn{2}{|c|}{ Solvabilitas } & -7.17 & 29.10 & 1.7658 & 4.20761 \\
\hline \multicolumn{2}{|c|}{ Profitabilitas } & -0.64 & 0,23 & $-0,0058$ & 0,09373 \\
\hline
\end{tabular}

Sumber: Data sekunder diolah

Tabel 2 untuk variabel independen ukuran perusahaan dilihat dari total aset perusahaan. Total aset terendah perusahaan yakni sebesar Rp 157,702,767,000 dan total aset terbesar perusahaan sebesar Rp87,196,053,833,000. Selama 
periode penelitian rata-rata perusahaan memiliki total aset sebesar Rp1,166,872,995,031.

Laba/rugi operasi terendah yang dialami perusahaan adalah sebesar Rp30,010,345,628,580 yang menunjukkan rugi dari total Laba/Rugi berjalan operasi perusahaan. Laba/rugi operasi tertinggi sebesar Rp4,554,631,134,000 yang menunjukkan laba dari total laba/rugi operasi perusahaan. Nilai rata-rata laba/rugi yang dihasilkan tahun berjalan perusahaan sebesar Rp$71,809,374,175$ yang menunjukkan bahwa rata-rata laba/rugi keseluruhan adalah rugi.

Reputasi KAP mempunyai nilai minimum yaitu satu artinya bahwa reputasi KAP yang tidak berafiliasi dengan The Big Four yang paling sedikit yang digunakan dalam melakukan audit laporan keuangan sebuah perusahaan. Nilai maksimum sebesar dua artinya bahwa reputasi KAP yang berafiliasi dengan The Big Four yang paling sering digunakan dalam melakukan audit laporan keuangan sebuah perusahaan. Nilai rata-ratanya sebesar 1,47 yang artinya rata-rata perusahaan yang menggunakan KAP The Big Four dan Non Big Four seimbang. Hal ini menunjukkan bahwa perusahaan yang menggunakan jasa KAP The Big Four lebih sedikit dibandingkan yang menggunakan jasa KAP Non Big Four.

Rasio solvabilitas terendah yang dialami perusahaan yakni sebesar -7.17. Rasio solvabilitas tertinggi yang dialami perusahaan adalah 29.10. Rata-rata rasio solvabilitas yang dialami oleh perusahaan sebesar 1.7658 dari total solvabilitas keseluruhan. DER dapat dikatakan baik jika nilai rasionya di bawah $100 \%$, ketika nilai DER di atas 100\% maka hutang tersebut tidak baik. Rata-rata rasio solvabilitas perusahaan sebesar 1,7685 yang lebih tinggi dari 1 atau $100 \%$ dapat dikatakan tidak baik. Hal ini menunjukkan bahwa perusahaan kurang mampu melunasi hutang-hutangnya. Semakin tinggi tingkat solvabilitas menunjukkan kinerja perusahaan yang semakin buruk

Profitabilitas mempunyai nilai minimum yaitu $-0,64$ artinya bahwa nilai rasio profitabilitas perusahaan terendah yakni sebesar $-0,64 \%$. Nilai maksimum sebesar 0,23 artinya bahwa rasio profitabilitas perusahaan tertinggi sebesar $0,23 \%$. Nilai rata-rata profitabilitas yaitu $-0,0058$ yang artinya rata-rata rasio profitabilitas sebesar $-0,0058 \%$. Standar ROA yang baik yakni di atas $2 \%$ (Lestari, Ika, \& Sugiharto, 2007). Oleh karena itu, dapat dikatakan rata-rata profitabilitas yang diperoleh perusahaan di bawah dari standar profitabilitas yang baik. Hal ini menunjukkan bahwa kinerja perusahaan kurang baik. 


\section{Uji Normalitas Data}

\section{Tabel 3. Uji Normalitas}

\begin{tabular}{lllll}
\hline No & Variabel & K-S & Sig & Keterangan \\
\hline 1 & Ukuran Perusahaan (X1) & 0,252 & 0,000 & Tidak Normal \\
2 & Laba Rugi Usaha (X2) & 0,393 & 0,000 & Tidak Normal \\
3 & Reputasi KAP (X4) & 0,355 & 0,000 & Tidak Normal \\
4 & Solvabilitas (X5 & 0,310 & 0,000 & Tidak Normal \\
5 & Profitabilitas (X6) & 0,372 & 0,000 & Tidak Normal
\end{tabular}

Sumber: Data sekunder diolah

Tabel 3 menunjukkan angka signifikansi pada variabel ukuran perusahaan (X1) laba/rugi operasi (X2) reputasi KAP (X3) solvabilitas (X4) dan profitabilitas (X5) sebesar 0,000 atau $\mathrm{p}=0,000$ artinya 0,000 $<0,05$ sehingga dapat disimpulkan bahwa data tidak terdistribusi normal. Hasil ini menjadi dasar untuk uji beda yang digunakan yaitu uji beda non parametrik.

\section{Ukuran Perusahaan}

Tabel 4 menunjukkan mean rank ukuran perusahaan antara yang terlambat dengan yang tepat waktu adalah berbeda. Pada ukuran perusahaan yang terlambat menunjukan rata-rata peringkat (mean rank) sebesar 44,81. Angka tersebut lebih rendah dari solvabilitas yang tepat waktu yaitu sebesar 58,73.

Tabel 4. Hasil Pengujian Mann-Whitney Ukuran Perusahaan

\begin{tabular}{llll}
\hline SIZE & $\mathrm{N}$ & Mean Rank & Sum Of Ranks \\
\hline Terlambat & 53 & 44,81 & 2375,00 \\
Tepat Waktu & 49 & 58,73 & 2878,00 \\
Total & 102 & & \\
\hline Asymp. Sig. (2-tailed) & 0,018 & & \\
\hline
\end{tabular}

Sumber: Data sekunder diolah

Dengan membandingkan angka probabilitas, diketahui bahwa signifikansi untuk dua sisi menunjukkan angka 0,018<0,05, maka dapat dinyatakan bahwa adanya perbedaan secara signifikan mengenai ukuran perusahaan pada laporan keuangan yang tepat waktu dengan laporan keuangan yang terlambat di penyampaian.

\section{Laba Rugi Operasi}

Tabel 5. Hasil Pengujian Mann-Whitney Laba Rugi Operasi

\begin{tabular}{llll}
\hline LABA RUGI & N & Mean Rank & Sum Of Ranks \\
\hline Terlambat & 53 & 45,42 & 2407,00 \\
Tepat Waktu & 49 & 58,08 & 2846,00 \\
Total & 102 & & \\
\hline
\end{tabular}


Asymp. Sig. (2-tailed) $\quad 0,031$

Sumber: Data sekunder diolah

Tabel 5 menunjukkan mean rank Laba rugi operasi antara yang terlambat dengan yang tepat waktu adalah berbeda. Pada laba rugi operasi yang terlambat menunjukan rata-rata peringkat (mean rank) sebesar 45,42. Angka tersebut lebih rendah dari laba rugi operasi yang tepat waktu yaitu sebesar 58,08 .

Dengan membandingkan angka probabilitas, diketahui bahwa signifikansi untuk dua sisi menunjukkan angka 0,031 $<0,05$ maka dapat dinyatakan bahwa adanya perbedaan secara signifikan mengenai laba rugi operasional perusahaan pada laporan keuangan yang tepat waktu dengan laporan keuangan yang terlambat di penyampaian.

\section{Reputasi KAP}

Tabel 6. Hasil Pengujian Mann-Whitney Reputasi KAP

\begin{tabular}{llll}
\hline REPUTASI KAP & N & Mean Rank & Sum Of Ranks \\
\hline Terlambat & 53 & 60,22 & 3191,50 \\
Tepat Waktu & 49 & 42,07 & 2061,50 \\
Total & 102 & & \\
\hline Asymp. Sig. (2-tailed) & 0,000 & & \\
\hline
\end{tabular}

Sumber: Data sekunder diolah

Tabel 6 menunjukkan mean rank reputasi KAP antara yang terlambat dengan yang tepat waktu adalah berbeda. Pada reputasi KAP yang terlambat menunjukan rata-rata peringkat (mean rank) sebesar 60,22. Angka tersebut lebih besar dari reputasi KAP yang tepat waktu yaitu sebesar 42,07.

Dengan membandingkan angka probabilitas, diketahui bahwa signifikansi untuk 2 sisi menunjukkan angka $0,000<0,05$, maka dapat dinyatakan bahwa adanya perbedaan secara signifikan mengenai reputasi KAP perusahaan pada laporan keuangan yang tepat waktu dengan laporan keuangan yang terlambat di penyampaian laporan keuangannya.

\section{Solvabilitas}

Tabel 7. Hasil Pengujian Mann-Whitney Solvabilitas

\begin{tabular}{llll}
\hline SOLVABILITAS & N & Mean Rank & Sum Of Ranks \\
\hline Terlambat & 53 & 52,42 & 2778,50 \\
Tepat Waktu & 49 & 50,50 & 2474,50 \\
Total & 102 & & \\
\hline Asymp. Sig. (2-tailed) & 0,743 & & \\
\hline
\end{tabular}

Sumber: Data sekunder diolah

Tabel 7 menunjukkan mean rank Solvabilitas antara yang terlambat dengan yang tepat waktu adalah berbeda. Pada Solvabilitas yang terlambat 
menunjukan rata-rata peringkat (mean rank) sebesar 52,42. Angka tersebut lebih besar dari solvabilitas yang tepat waktu yaitu sebesar 50,50.

Dengan membandingkan angka probabilitas, diketahui bahwa signifikansi untuk dua sisi menunjukkan angka 0,743>0,05, maka dapat dinyatakan bahwa tidak adanya perbedaan secara signifikan mengenai solvabilitas perusahaan pada laporan keuangan yang tepat waktu dengan laporan keuangan yang terlambat di penyampaian. Oleh karena itu, baik laporan keuangan auditan yang disampaikan tepat waktu dengan laporan keuangan auditan yang $\mathrm{d}$ penyampaian terlambat tidak memiliki perbedaan pada rasio solvabilitasnya.

\section{Profitabilitas}

Tabel 8. Hasil Pengujian Mann-Whitney Profitabilitas

\begin{tabular}{llll}
\hline PROFITABILITAS & N & Mean Rank & Sum Of Ranks \\
\hline Terlambat & 53 & 46,37 & 2457,50 \\
Tepat Waktu & 49 & 57,05 & 2795,50 \\
Total & 102 & & \\
\hline Asymp. Sig. (2-tailed) & \multicolumn{2}{c}{0,057} & \\
\hline
\end{tabular}

Sumber: Data sekunder diolah

Tabel 8 menunjukkan mean rank profitabilitas antara yang terlambat dengan yang tepat waktu adalah berbeda. Pada profitabilitas yang terlambat menunjukan rata-rata peringkat (mean rank) sebesar 46,37. Angka tersebut lebih rendah dari profitabilitas yang tepat waktu yaitu sebesar 57,05.

Dengan membandingkan angka probabilitas, penelitian ini menemukan bahwa signifikansi untuk dua sisi menunjukkan angka 0,057 >0,05, maka dapat dinyatakan bahwa tidak ada perbedaan secara signifikan mengenai profitabilitas perusahaan pada laporan keuangan yang tepat waktu dengan laporan keuangan yang terlambat di penyampaian. Dengan demikian dapat disimpulkan baik laporan keuangan auditan yang disampaikan tepat waktu dengan laporan keuangan auditan yang terlambat di penyampaian tidak memiliki perbedaan pada tingkat rasio profitabilitas.

\section{Pembahasan}

Ukuran perusahaan pada laporan keuangan auditan yang tepat waktu berbeda dengan ukuran perusahaan pada laporan keuangan auditan yang terlambat. Semakin besar ukuran perusahaan maka berdampak pada keterlambatan penyampaian laporan keuangan auditan. Hal ini sejalan dengan penelitian Juniati (2016); Panjaitan, Wahidahwati, \& Amanah (2013); Astuti \& Erawati (2018); serta Rachmawati (2008) yang membuktikan bahwa ukuran perusahaan mempengaruhi keterlambatan ataupun ketepatwaktuan penyampaian laporan keuangan. Hal ini dapat terjadi kemungkinan karena 
perusahaan dengan ukuran yang besar memerlukan waktu lebih lama untuk memproses laporan keuangannya.

Laba rugi operasi pada laporan keuangan auditan yang tepat waktu berbeda dengan laba rugi operasi pada laporan keuangan auditan yang terlambat. Laba rugi operasi pada laporan keuangan auditan yang tepat waktu kemungkinan cenderung memiliki laba lebih tinggi dibandingkan laba rugi operasi pada laporan keuangan auditan yang terlambat yang memiliki rugi. Hal ini dikarenakan perusahaan akan lebih cepat meyampaikan laporan keuangannya ketika labanya tinggi untuk menarik minat investor dalam investasi saham pada perusahaan tersebut. Perusahaan yang mendapatkan laba tinggi akan tepat waktu dalam mempenyampaian laporan keuangan auditannya. Hal ini sejalan dengan penelitian Kartika (2011) yang membuktikan bahwa laba rugi operasi berpengaruh terhadap lamanya waktu audit yang berdampak pada waktu penyampaian laporan keuangan.

Reputasi KAP pada laporan keuangan auditan yang tepat waktu berbeda dengan ukuran perusahaan pada laporan keuangan auditan yang terlambat. Reputasi KAP pada laporan keuangan auditan yang tepat waktu cenderung berafiliasi dengan KAP The Big Four dibandingkan ukuran perusahaan pada laporan keuangan auditan yang terlambat yang cenderung menggunakan KAP Non Big Four. Hal ini sejalan dengan penelitian Irman (2017) yang membuktikan bahwa reputasi auditor mempengaruhi ketepatan waktu pelaporan keuangan. Hal ini kemungkinan dapat terjadi dikarenakan KAP The Big Four yang memiliki reputasi yang tinggi dan dapat dipercaya sehingga lebih tepat waktu dalam pelaporan laporan keuangan auditan.

Solvabilitas pada laporan keuangan auditan yang disampaikan tepat waktu dan pada laporan keuangan auditan yang di penyampaian terlambat tidak memiliki perbedaan yang baik pada tingkat solvabilitas yang tinggi maupun rendah. Seberapa besar atau kecilnya kemampuan perusahaaan melunasi utangnya tidak berdampak pada waktu laporan keuangan auditan di penyampaian. Tingkat solvabilitas perusahan baik tinggi maupun rendah juga kemungkinan berdampak kecil pada keterlambatan penyampaian keuangan karena auditor sudah memiliki standar waktu pekerjaan bagi siklus akuisisi dan pembayaran hutang perusahaan (Arens, Elder, Beasley, \& Hogan, 2017). Banyaknya hutang yang outstanding tidak akan menambah atau mengurangi agihan (standar) waktu pekerjaan tersebut. Hasil penelitian ini juga sejalan dengan penelitian Juniati (2016) yang menyatakan bahwa solvabilitas tidak berpengaruh terhadap keterlambatan penyampaian laporan keuangan. Hal ini berarti besar kecilnya kemampuan perusahaan melunasi hutang jangka panjangnya tidak berpengaruh terhadap ketepatan waktu penyampaian laporan keuangan auditan. 
Profitabilitas pada laporan keuangan auditan yang disampaikan tepat waktu dengan laporan keuangan auditan yang di penyampaian terlambat tidak memiliki perbedaan yang signifikan baik pada tingkat profit yang tinggi maupun rendah. Hal ini kemungkinan dapat disebabkan karena baik perusahaan memiliki profitabilitas yang tinggi maupun rendah auditor tidak akan menghabiskan lebih banyak atau sedikit waktu untuk melakukan prosedur audit, dengan kata lain jumlah agihan waktu audit yang diberikan auditor akan sama. Penelitian ini sejalan dengan penelitian Probokusumo, Utomo, \& Nuraina (2017) dan Rachmawati (2008) yang membuktikan bahwa profitabilitas tidak berpengaruh terhadap ketepatan waktu penyampaian laporan keuangan. Hal ini berarti besar kecilnya keuntungan yang didapatkan oleh perusahaan tidak berpengaruh terhadap ketepatan waktu penyampaian laporan keuangan auditan.

\section{Simpulan}

Berdasarkan hasil penelitian ini maka dapat disimpulkan bahwa terdapat perbedaan ukuran perusahaan, laba rugi operasi, dan reputasi KAP pada laporan keuangan auditan yang disampaikan tepat waktu dan laporan keuangan auditan yang di penyampaian terlambat (tidak tepat waktu). Akan tetapi tidak ada perbedaan solvabilitas dan profitabilitas pada laporan keuangan auditan yang disampaikan tepat waktu dan laporan keuangan auditan yang di penyampaian terlambat dalam perusahaan pertambangan yang tercatat di BEI untuk periode 2014-2016.

Penelitian ini memiliki beberapa keterbatasan di dalam penulisannya, yaitu: pertama, terdapat beberapa perusahaan yang laporan keuangannya tidak secara lengkap diterbitkan pada IDX sehingga tidak dapat dilakukan pengujian terhadap laporan keuangan tersebut. Kedua, penelitian ini hanya melihat perbedaan faktor-faktor antara perusahaan yang terlambat maupun tidak terlambat dan bukan merupakan penelitian dengan pengujian yang mendalam. Ketiga, penelitian ini hanya sebatas melihat angka-angka yang terjadi dalam ranah penyajian laporan keuangan tanpa melihat fenomena aktual dari eksternal perusahaan yang sebenarnya dapat berdampak pada ketepatan waktu penyampaian laporan keuangan.

Penelitian selanjutnya sebaiknya dapat mencari sumber data yang memadai untuk dapat melengkapi keseluruhan objek perusahaan pertambangan yang ada di Indonesia. Selanjutnya pengujian mendalam diperlukan untuk dapat melihat bagaimana sebenarnya dampak dari masing-masing faktor yang diteliti pada penelitian ini. Selain itu fenomena eksternal perlu menjadi pertimbangan penelitian selanjutnya untuk mengembangkan kerangka penelitian. 


\section{Daftar Pustaka}

Alkhatib, K., \& Marji, Q. (2012). Audit Report Timeliness: Empirical Evidence From Jordan. Social And Behavioral Science, 1342-1349.

Apriyana, N., \& Rahmawati, D. (2017). Pengaruh Profitabilitas, Solvabilitas, Ukuran Perusahaan, dan Ukuran Kap Terhadap Audit Delay pada Perusahaan Properti Dan Real Estate Yang Terdaftar Di Bursa Efek Indonesia Periode 2013-2015. Jurnal Nominal, 108-124.

Arens, A. A., Elder, R. J., Beasley, M. S., \& Hogan, C. E. (2017). Auditing and Assurance Services, 16th Global Edition. Michigan: Pearson.

Astuti, W., \& Erawati, T. (2018). Pengaruh Profitabilitas, Umur Perusahaan dan Ukuran Perusahaan Terhadap Ketepatan Waktu Penyampaian Laporan Keuangan Perusahaan. Jurnal Kajian Bisnis, 26, Nomor 2, 144-157.

Ikatan Akuntansi Indonesia. (2018). Standar Akuntansi Keuangan. Jakarta: Salemba Empat.

Irman, M. (2017). Pengaruh Ukuran Perusahaan, ROA, DER, dan Reputasi Auditor Terhadap Audit Delay. Journal of Economic, Business, and Accounting (Costing), 1(1), 23-34.

Juniati, E. (2016). Analisis Faktor yang Mempengaruhi Keterlambatan Penyampaian Laporan Keuangan Pada Perusahaan Pertambangan yang Terdaftar Di Bursa Efek Indonesia Periode Tahun 2010-2013. JOM Fekon Vol 3 No.1.

Kartika, A. (2011). Faktor - Faktor Yang Mempengaruhi Audit Delay Pada Perusahaan Manufaktur yang Terdaftar di BEI. Dinamika Keuangan dan Perbankan, Vol 3, No. 2, 152-171.

Lestari, Ika, M., \& Sugiharto, T. (2007). Kinerja Bank Devisa dan Bank Non Devisa Dan Faktor-Faktor Yang Mempengaruhinya. Proceeding Pesat (Psikologi, Ekonomi, Sastra, Arsitek \& Sipil), Vol 2, No. 1, 195-201.

Mareta, S. (2015). Analisis Faktor-Faktor Yang Memengaruhi Timeliness Publikasi Laporan Keuangan Periode 2009-2010 (Studi Empiris Pada Bursa Efek Indonesia). Jurnal Akuntansi/Volume Xix, 93-108.

Melani, A. (2017, Juli 3). Belum Sampaikan Laporan Keuangan, Bei Suspensi 17 Saham Emiten. Dipetik Maret 27, 2018, Dari Http://Www.Liputan6.Com/Bisnis/Read/3009365/Belum-SampaikanLaporan-Keuangan-Bei-Suspensi-17-Saham-Emiten

Mubarok, A. (2016). Faktor - Faktor Yang Mempengaruhi Audit Delay Dan Relevansinya Terhadap Timeliness (Studi Empiris Pada Perusahaan Manufaktur Di Bursa Efek Indonesia). Jurnal Manajemen Dan Jurnal Akuntansi, Vol XIX, No. 1, 50-67.

Nabhani, A. (2015, April 10). Harian Ekonomi Neraca. Dipetik Maret 20, 2018, Dari Http://Www.Neraca.Co.Id/Article/52481/Payah-52-Emiten-Telat-LaporkanKeuangan

Panjaitan, Z. F., Wahidahwati, \& Amanah, L. (2013). Faktor-Faktor Yang Mempengaruhi Audit Delay dan Timeliness atas Penyampaian Laporan Keuangan. Jurnal Ilmu \& Riset Akuntansi Vol.2 No.11, 1-12.

Pasopati, G. (2016, Juni 30). Telat Sampaikan Lapkeu, BEI Suspensi Saham 18 Perusahaan. Dipetik Maret 27, 2018, Dari Https://Www.Cnnindonesia.Com/Ekonomi/20160630145045-92142141/Telat-Sampaikan-Lapkeu-Bei-Suspensi-Saham-18-Perusahaan

Probokusumo, E., Utomo, S. W., \& Nuraina, E. (2017). Pengaruh Profitabilitas, Solvabilitas dan Size Perusahaan Terhadap Timeliness Pelaporan Keuangan (Studi Empiris Pada Perusahaan Manufaktur yang Terdaftar Di BEI). The 9th Fipa: Forum Ilmiah Pendidikan Akuntansi, Vol. 2, No. 1, 110-119. 
Puspitasari, E., \& Sari, A. N. (2012). Pengaruh Karakteristik Perusahaan Terhadap Lamanya Waktu Penyelesaian Audit (Audit Delay) pada Perusahaan Manufaktur Yang Terdaftar Di Bursa Efek Indonesia. Jurnal Akuntansi \& Auditing, Vol. 9, No. 1, 31-42.

Rachman, D. A. (2016). Analisis Faktor - Faktor Yang Mempengaruhi Audit Delay Pada Perusahaan Telekomunikasi. Jurnal Ilmu Dan Riset Akuntansi, Vol. 5, No. 7, 113.

Rachmawati, S. (2008). Pengaruh Faktor Internal Dan Eksternal Perusahaan Terhadap Audit Delay Dan Timeliness. Jurnal Akuntansi Dan Keuangan Vol. 18, 1-10.

Sari, I. P., Setiawan, R. A., \& Ilham, E. (2014). Pengaruh Ukuran Perusahaan, Solvabilitas Dan Reputasi Kap Terhadap Audit Delay Pada Perusahaan Property \& Real Estate Di Bursa Efek Indonesia Periode 2009-2012. JOM Fekon Vol. 1 No. 2, 115.

Sukirno. (2015, Juni 30). Bei Suspensi 6 Emiten. BORN, BUMI, BRAU Termasuk. Dipetik Maret 27, 2018, Dari Http://Market.Bisnis.Com/Read/20150630/192/448571/Bei-Suspensi-6Emiten.-Born-Bumi-Brau-Termasuk

Tamba, C. (2010). Faktor - Faktor yang Mempengaruhi Audit Delay. Media Riset Akuntansi, Auditing \& Informasi, 5, 271-285.

Wariyanti, \& Suryono, B. (2017). Pengaruh Profitabilitas, Leverage dan Opini Audit Terhadao Audit Delay. Jurnal Ilmu Dan Riset Akuntansi, Vol. 6, September, 1364-1379. 